\title{
Financing Consumer Goods under the Uniform Commercial Code: Installment Buyers and Defaulting Sellers
}

Many consumer goods are purchased today by means of credit sales rather than on a cash basis. Such credit sales usually provide for payment of the purchase price in installments. ${ }^{1}$ Some large sellers may finance their own sales, but more commonly a finance company or bank becomes the creditor. ${ }^{2}$ In the typical transaction the buyer executes a promissory note, a conditional sales contract, or both, payable to the seller. ${ }^{3}$ The seller who does not wish his profits invested in commercial paper will assign the documents to a financing agency for cash. Thereafter, the buyer will find himself obligated, not to the merchant with whom he initially dealt, but to a financer with whom he has had no previous contact. This change will have no effect on the buyer so long as all of the parties to the contract perform their obligations. However, if the seller fails to perform, the situation becomes much more complicated.

Ordinarily, upon the seller's default, the buyer would stop making payments until the seller resumed performance. Not only would this be the buyer's cheapest and simplest remedy, but it also may appear as his only reasonable course of action. Frequently, however, the defaulting seller has disappeared or become insolvent so that even though the buyer has a cause of action against the seller, such cause of action is of little, if any value. Moreover, once the security agreements are in the hands of a financer, the buyer may find that the simple remedy of withholding payment is not available. The financer will probably

1 J. Chapman \& R. Shay, The Consumer Financing Industry 2-3 (1967); P. McCracken, J. Máo \& C. Fricke, Consumer installment Credit and Public Policy 7-8 (1965).

2 A 1962 study of consumer credit in the United States showed that eighty-seven per cent, of consumer installment credit was provided by financing institutions and that only thirteen per cent was provided by retail outlets such as automobile dealers and furniture stores. P. McCracken, J. MAo \& C. Fricke, supra note 1 , at 8.

3 The security instruments used in such cases vary according to state law. Some states have forbidden the use of promissory notes in such sales. See Comment, The Holder-inDue-Course Concept and the Installment Buyer of Consumer Goods, 36 U.M.K.C.L. REv. 368, 379 \& nn. 57 \& 58 (1968); 75 Harv. L. Rev. 437, 438-9 (1961). While elimination of the note will remove the problem of recovery on the negotiable instrument, the other major problem discussed in this comment, use of waiver of defenses clauses in consumer sales contracts, will remain. 
bring suit against the buyer who stops making payments, and it will claim to be the beneficiary of any waiver of defenses ${ }^{4}$ included in the contract, a holder in due course of the note, or both. If its claim to these positions is sustained, the financer will succeed in any suit against the buyer predicated on the security documents. The result of allowing such protected status ${ }^{5}$ is that the consumer pays for goods which he never received. ${ }^{6}$

A close and intimate connection between the financer and the seller complicates the situation with respect to the financer's status as a holder in due course. The seller may own the finance company and have created it for the single purpose of taking paper resulting from the seller's sales. In other situations, the financer, while not owned by the seller or their common parent company, may have extremely close relations with the seller. Such a relationship is usually evidenced by an agreement setting out the financer's rights, and giving it some measure of control over the seller's business. Such control may include rights to inspect any of the seller's records, to provide forms for use in the seller's sales, and to veto proposed sales by the seller. This relationship may be seen by the court as reason to deny the financer the protected status given to a holder in due course.

The problem of the "closely associated" financer has been considered by the courts for over thirty years beginning with the leading case of Commercial Credit Company v. Childs. ${ }^{7}$ Childs and its progeny, ${ }^{8}$ which

4 A typical waiver of defenses clause is quoted at note 23 infra.

5 The term "protected status" in this comment refers to a financer who qualifies as a holder in due course, the beneficiary of a waiver of defenses clause, or both.

6 If the seller is not insolvent and has not disappeared, the buyer's cause of action against him has value. However, if the courts required that consumers continue paying the financer and bring their own actions against the seller, the consumers would have to incur legal expenses which would be unnecessary if they could simply stop making payments to the financer. It is further submitted that in the case of consumers at or near the poverty level, suits against the seller would frequently not be brought because of lack of knowledge or distrust of the legal system, or from fear that in the future credit would be totally unavailable.

7199 Ark. 1073, 137 S.W.2d 260 (1940). An earlier case which came to the same conclusions but did not make references to the Negotiable Instruments Law was Buffalo Indus. Bank v. DeMarzio, 162 Misc. 742, 296 N.Y.S. 783, rev'd on other grounds, 6 N.Y.S.2d 568 (1937).

8 See, e.g., Commercial Credit Corp. v. Orange County Machine Works, 34 Cal. 2d 766, 214 P.2d 819 (1950); Mutual Finance Co. v. Martin, 63 So. 2d 649 (Fla. 1953).

In deciding the last cited case the Florida Supreme Court said:

It may be that our holding here will require some changes in business methods and will impose a greater burden on the finance companies. We think the buyer -Mr. \& Mrs. General Public-should have some protection somewhere along the line. We believe the finance company is better able to bear the risk of the dealer's insolvency than the buyer and is in a far better position to protect his interests against unscrupulous and insolvent dealers. Id. at 653.

Williams v. Walker-Thomas Furniture Co., 350 F.2d 445 (D.C. Cir. 1965); International 
arose before the adoption of the Uniform Commercial Code (UCC), were generally decided under the Negotiable Instruments Law (NIL). Those cases denied protected status to the financer against the consumer because of the financer's intimate relationship with the seller. There have been relatively few decisions, however, concerning the protection which the UCC affords to consumers in similar situations. The recent New Jersey case of Unico $v$. Owen, ${ }^{9}$ which involved the question of the "closely associated" financer, is a leading case for protection of the consumer under the UCG in the situation outlined. The decision was reached under the NIL, but the court stated that it would have reached the same results under the UCG. ${ }^{10}$ While the decision would appear to be a strong precedent for consumer protection, several commentators have been highly critical of it and have attacked it as unauthorized by the Code. ${ }^{11}$

This comment, in examining the rationale of Unico $v$. Owen, will consider the protection which the UCC gives to the consumer installment buyer when the seller under an executory contract defaults, ${ }^{12}$ and the financer, as assignee of the security agreements, attempts to collect the remaining balance of the obligations owed by buyer. It will first consider the problem of waiver of defenses clauses in consumer sales contracts and the protection accorded by the UCC to consumers against enforcement of such clauses. Secondly, it will consider whether the

Finance Corp. v. Rieger, 272 Minn. 192, 137 N.W.2d 172 (1965); Local Acceptance Co. v. Kinkade, 361 S.W.2d 830 (Mo. 1962); contra, Implement Credit Corp. v. Elsinger, 268 Wis. 143, 66 N.W.2d 657 (1954).

9 50 N.J. 101, 232 A.2d 405 (1967). The opinion was written for a unanimous court by Francis, J., who had written the court's opinion in the leading consumer protection case of Henningsen v. Bloomfield Motors, 32 N.J. 358, 161 A.2d 69 (1960).

1050 N.J. 101, 109, 282 A.2d 405, 409-10. The note in question was executed November 6, 1962 and while the UCC had been adopted by the legislature in 1961, it did not become effective until January $1,1968$.

11 The harshest criticisms are found in Comment, Unico v. Owen, Consumer Finance Companies as Holders in Due Course Under the Uniform Commercial Code, 54 VA. L. REv. 279 (1968); and Recent Decisions, Unconscionability and the Consumer's Waiver of Defenses, 56 Gro. L.J. 997 (1968). These commentaries criticize the use made by the court of both the holder in due course and the waiver of defenses provisions of the Code. For the specific objections see text accompanying notes 30 and 31 infra.

12 The problem of failure of consideration by the installment seller will be the basic problem discussed in this comment. A similar problem is that of breach of warranty. The financer will demand payment for the goods even if they do not meet the seller's warranty. If the consumer was obligated to continue making all his payments on the defective goods, he would be in nearly as bad a position as if he had never received them. However, unlike in the failure of consideration situation, the seller has probably not breached his warranty because of insolvency. Therefore, an action against the seller of defective goods is much more worthwhile than an action against one who has failed to perform at all. In several of the situations discussed in this comment, though, breach of warranty could probably be used as an effective defense. See notes 52 \& 89 infra. 
financer who is closely associated with the seller is entitled to holder in due course status of a note executed by the consumer.

\section{UNICO V. OWEN}

Unico involved a sale of records and a stereo to Owen by Universal Stereo Corporation. Owen had answered a newspaper advertisement as a result of which Universal's salesman called at his home and explained that by purchasing one hundred and forty record albums, Owen would receive a stereo free. Impressed with this offer, Owen signed a "retail installment contract" which would entitle him to receive twelve albums immediately and twelve more albums every six months until he had received the agreed upon number. ${ }^{13}$ In addition to the sales contract, Owen and his wife executed a promissory note to Universal. Both documents provided that the contract price be paid in thirty-six equal monthly installments. ${ }^{14}$ On the same day that these documents were executed, Universal assigned them to Unico. Both the note and the sales contract used in the transaction had been provided by Unico and each included an assignment form on which Unico's name was printed as assignee. ${ }^{15}$ Following this initial transaction, Owen made his monthly payments for one year. During that period, however, Universal became insolvent, and as a result, only the stereo and twelve of the promised albums were ever delivered. When Owen then stopped making payments, Unico contacted him immediately and demanded that payments be resumed. Owen refused, and shortly thereafter Unico sued for the unpaid balance of the purchase price. ${ }^{16}$

At this point it is instructive to examine the circumstances surrounding Unico's formation and the structure of its operations. Unico, a partnership, was formed for the single purpose of buying from Universal commercial paper resulting from the latter's sales of stereos and records. Universal paid the organization expenses of Unico, ${ }^{17}$ and immediately Universal and Unico made an agreement providing for the assignment

1350 N.J. 101, 104, 232 A.2d 405, 407 (1967).

14 Id. The total contract price was $\$ 849.72$ which was the sum of: cash price $\$ 698$; official fee $\$ 1.40$; and time-price differential $\$ 150.32$. A down payment of $\$ 30$ had been made and the monthly installments were $\$ 22.77 . I d$. The court noted the "hyper-executory character of the performance agreed to by Universal," referring to the fact that the entire purchase price was to be paid in three years while delivery of the record albums would not be completed for $51 / 3$ years. Id. at 107, 232 A.2d at 408-9.

15 The contract and note were dated November 6, 1962. The assignment was a printed form which included Unico's name. While it was not dated, Unico conceded that it was signed the same day that the documents were executed. Id. at 108, $232 \mathrm{~A} .2 \mathrm{~d}$ at 409.

16 Id. at 108-9, 232 A.2d at 409.

17 Id. at 114,232 A.2d at 412 . The opinion does not state whether all of the partners of Unico were officers or owners of Universal. 
of Universal's paper to Unico. ${ }^{18}$ The agreement gave Unico various measures of influence over Universal's business and means by which it could remain informed of all aspects of Universal's affairs. It gave Unico unlimited authorization to inspect Universal's records, provided that Unico's representatives could be on Universal's premises at any time, and required that forms furnished by Unico be used in all of Universal's credit transactions. ${ }^{19}$ That Unico thus had virtual control over Universal and the opportunity to remain cognizant of all of its dealings is apparent, and it indicates a situation much different from a disinterested financer taking paper from a number of sellers. As a result the court found that:

the terms of the record sales agreement ... were designed to put the buyer-consumer in an unfair and burdensome legal strait jacket ... permitting the noteholder, . . . to force payment ... by enveloping itself in the formal status of due course. To say the relationship ... was close, and that Unico was involved therein, is to put it mildly. ${ }^{20}$

When Unico sued for the unpaid portion of the contract price, Owen's principal defense was that Unico was not entitled to holder in due course status and that Universal's failure of consideration thus barred Unico's recovery. ${ }^{21}$ The trial court held that Unico was not a holder in due course and gave judgment for Owen. ${ }^{22}$ On appeal the New Jersey Supreme Court considered two issues: (1) Unico's claim to holder in due course status and (2) the effect on Unico's right to recover of the waiver of defenses clause in the sales contract. ${ }^{23}$ In considering Unico's claim of holder in due course status, the court first reviewed pre-Code decisions from other jurisdictions which had held

18 After stating the nature of Universal's business, the agreement provided that Unico would "lend" Universal up to thirty-five per cent of the balances of customers' contracts subject to a $\$ 50,000$ maximum. As "collateral security," Universal agreed to negotiate all of its customers' notes and assign all conditional sales contracts to Unico. $I d$. at 114,232 A.2d at 412 .

19 Id. at $114-5,232$ A.2d at 412 .

20 Id. at $115-6,232$ A.2d at 418.

21 This may be pleaded under UNIForM COMMERciat Code § 3-306 [hereinafter cited as UCC] once holder in due course status is denied.

2250 N.J. 101, 109, 232 A.2d 405, 409 (1967).

23 The waiver clause provided: "Buyer hereby acknowledges notice that the contract may be assigned and that assignees will rely upon the agreements contained in this paragraph, and agrees that the liability of the Buyer to any assignee shall be immediate and absolute and not affected by any default whatsoever of the Seller signing this contract; and in order to induce assignees to purchase this contract, the Buyer further agrees not to set up any claim against such Seller as a defense, counterclaim or offset to any action by any assignee for the unpaid balance of the purchase price or for possession of the property." Id. at 106, 232 A.2d at 408. 
that an extremely close relationship between the financer and seller constituted grounds for denying the protected status to the financer. "For reasons of equity and justice,"24 the New Jersey court approved such a denial stating:

[f]or purposes of consumer goods transactions, we hold that where the seller's performance is executory in character and when it appears from the totality of arrangements between dealer and financer that the financer has had a substantial voice in setting standards for the underlying transaction, or has approved the standards established by the dealer, and has agreed to take all or a predetermined or substantial quantity of the negotiable paper which is backed by such standards, the financer should be considered a participant in the original transaction and therefore not entitled to holder in due course status. $^{25}$

In considering Unico's second argument, the court held the waiver clause unenforceable because it was opposed to the provisions of the NIL and because the policy of New Jersey is to protect conditional vendees against imposition by conditional vendors and installment sellers. ${ }^{26}$ The basis for the same conclusion under the UCC was section 9-206(1).27 The court stated that section 9-206(1) "must as a matter of public policy be closely linked with section 2-302,"28 adding that:

We see in the enactment of these two sections of the Code an intention to leave in the hands of the courts the continued application of common law principles in deciding in consumer

24 Id. at $116,232 \mathrm{~A} .2 \mathrm{~d}$ at 413 .

$25 \mathrm{Id}$. at 122-3, $232 \mathrm{~A} .2 \mathrm{~d}$ at 417 . (Emphasis added.)

$26 I d$. at 124,232 A.2d at $417-8$.

27 UCC \& 9-206(I) provides:

Subject to any statute or decision which establishes a different rule for buyers or lessees of consumer goods, an agreement by a buyer or lessee that he will not assert against an assignee any claim or defense which he may have against the seller or lessor is enforceable by an assignee who takes his assignment for value, in good faith and without notice of a claim or defense, except as to defenses of a type which may be asserted against a holder in due course of a negotiable instrument under the Article on Commercial Paper .... A buyer who as part of one transaction signs both a negotiable instrument and a security agreement makes such an agreement.

2850 N.J. 101, 125, 232 A.2d 405, 418 (1967). UCC \$ 2-302 provides:

(1) If the court as a matter of law finds the contract or any clause of the contract to have been unconscionable at the time it was made the court may refuse to enforce the contract, or it may enforce the remainder of the contract without the unconscionable clause, or it may so limit the application of any unconscionable clause as to avoid any unconscionable result. (2) When it is claimed or appears to the court that the contract or any clause thereof may be unconscionable the parties shall be afforded a reasonable opportunity to present evidence as to its commercial setting, purpose and effect to aid the court in making the determination. 
goods cases whether such waiver clauses as the one imposed on Owen in this case are so one-sided as to be contrary to public policy. ${ }^{29}$

The result of Unico is that the consumer in New Jersey has the same protection under the UCC which the majority of states would have given him in the same situation under the NIL.

The use of the UCG by the New Jersey court represents desirable and valuable consumer protection. However, both the holder in due course and waiver of defenses portions of the decision have been criticized as unauthorized by the Code. One commentator attacked the denial of holder in due course status as an improper use of the good faith requirement of the Code, concluding that denial based on the relationship between seller and financer is unauthorized. ${ }^{30}$ The decision has also been attacked on the basis of the court's interpretation of section 9-206. Critics see this section as designed to save pre-Code judicial and statutory prohibitions of the use of waivers but not as authorization for the court to establish such prohibitions. ${ }^{31}$ Commentators suggest that courts should wait for the adoption of further uniform legislation ${ }^{32}$ such as the Uniform Consumer Credit Code, ${ }^{33}$ which would provide the same type of protection which the New Jersey court gave in Unico. ${ }^{34}$ However, until adoption of further legislation, courts should use the available provisions of the UCG to protect consumers. If the various criticisms of such use were valid, an important area of consumer protection would be undermined with the result that the consumer would be in a less favorable position under the Code than he was before its adoption.

2950 N.J. 101, 125, 232 A.2d 405, 418 (1967).

30 Comment, Unico v. Owen: Consumer Finance Companies as Holders in Due Course Under the Uniform Commercial Code, 54 VA. L. REv. 279, $286-92$ (1968). See notes 36 \& 75 infra for the Code's holder in due course and good faith requirements.

31 See Comment, Commercial Transactions: Section 9.206 and Its Applicability to the Tripartite Credit Card, 21 OKL.. L. REv. 59, 61.62 (1968); Recent Decisions, Unconscionability and the Consumer's Waiver of Defenses, 56 GEO. L.J. 997 (1968).

32 Comment, Unico v. Owen: Consumer Finance Companies as Holders in Due Course Under the Uniform Commercial Code, 54 VA. L. REv. 279, 292-4 (1968).

33 UNIFORM CONSUMER CREDIT CODE, Official Draft (1969) [hereinafter cited as UCCC].

34 The pertinent sections of the UCCC are:

\$ 2.403-Certain Negotiable Instruments Prohibited

In a consumer credit sale or consumer lease, ... the seller or lessor may not take a negotiable instrument other than a check as evidence of the obligation of the buyer or lessee. A holder is not in good faith if he takes a negotiable instrument with notice that it is issued in violation of this section....

$\S$ 2.404-Assignee Subject to Defenses

With respect to a consumer credit sale or consumer lease, ... an assignee of the rights of the seller or lessor is subject to all claims and defenses of the buyer or lessee against the seller or lessor arising out of the sale or lease notwithstanding an agreement to the contrary.... 


\section{Watver of Defenses Clauses in the Consumer Context}

In Unico the court considered first the contentions of the financer that it was entitled to holder in due course status and then considered the effect of the waiver clause in the sales contract. Unico maintained that even if it did not qualify as a holder in due course, the waiver clause entitled it to recovery. ${ }^{35}$ It was unnecessary, however, for the Unico court to consider this argument. A party who does not qualify as a holder in due course ${ }^{36}$ cannot claim rights equal to those of a holder in due course by virtue of being an assignee of the contract involved in the transaction. This is because section 9-206 includes the same requirements of taking for value, in good faith and without notice of defects, that one must meet to qualify as a holder in due course. Therefore the determination that Unico was not a holder in due course was conclusive as to its rights to recover from Owen, and the portion of the decision dealing with the independent waiver argument must be considered as dictum.

Nevertheless, the portion of the decision dealing with the waiver agreement is extremely important in the context of consumer protection. It is important first of all because it would be the basis for protection of the consumer in fact situations similar to Unico, but where a note was not used. The invalidation of consumer waiver agreements is of further importance because it will be effective to protect the consumer when the facts do not permit a denial of holder in due course status to a noteholder. ${ }^{37}$

\section{A. Section 9-206 and Consumer Waiver of Defenses Agreements}

Section 9-206 of the UCC includes one of the last vestiges in the Code of an original plan to include considerable consumer protection. ${ }^{38}$ The present version of the section, however, represents a retreat from earlier editions of the Code. The 1952 edition of the Code included an outright prohibition against use of waivers of defenses in consumer

35 See text at notes $26 \& 29$ supra.

36 UCC \& 3-302(1) provides:

(1) A holder in due course is a holder who takes the instrument

(a) for value; and

(b) in good faith; and

(c) without notice that it is overdue or has been dishonored or of any defense

against or claim to it on the part of any person

37 Frequently, as in Unico, the assignee of the contract would not qualify as a holder in due course because it did not meet the notice and good faith requirements of UCC \$ 3-302. However, even if it did meet such requirements, the protection given by $\$ 9-206$ would be effective because the provisions of the Code relating to chattel paper would be controlling. See text at notes 49 \& 50 infra.

38 See 2 G. Gilmore, Securtry Interests in Personal Property 1093 (1965); MentschiKOFr, Highlights of the Uniform Commercial Code, 27 Mod. L. REv. 167, 171 (1964). 
contracts providing that "[such an agreement] is not enforceable by any person." 30 Financing agencies strongly opposed this outright prohibition and felt that "there would inevitably follow chaos"40 in the consumer financing business, were it adopted. As a result of the vehement objection to the original version, it was changed to embody a compromise position. Thus, the present section gives general approval to the use of waiver of defenses agreements in commercial transactions, ${ }^{41}$ but permits an exception regarding their use in consumer transactions. The first sentence of the present section provides that waiver of defenses clauses are enforceable "[s]ubject to any statute or decision which establishes a different rule for buyers or lessees of consumer goods . . . ."42

The present language of the first sentence of section 9-206(1) has given rise to some uncertainty as to the scope of the consumer exception. The uncertainty has been increased by a few states which eliminated the words "or decision" from the sentence in their editions of the Code. ${ }^{43}$ As a result, several commentators see in the wording an intention only to preserve law existing at the time of the Code's adoption, and not an intention to authorize subsequent development of consumer-oriented exceptions to the basic rule of the section. They have referred to these interpretations as the "prior law" and "free hand" theories ${ }^{44}$ for use of the consumer provisions in the section. Accordingly they have concluded that the section was meant to follow the "prior law" theory and allows no post-Code judicial creation of consumer ex-

39 \& 9-206(l) of the 1952 edition of the Code provides:

(1) An agreement by a buyer of consumer goods as part of the contract for sale that he will not assert against an assignee any claim or defense arising out of the sale is not enforceable by any person. If such a buyer as part of one transaction signs both a negotiable instrument and a security agreement even a holder in due course of the negotiable instrument is subject to such claims or defenses if he seeks to enforce the security interest either by proceeding under the security agreement or by attaching or levying upon the goods in an action upon the instrument.

40 See 2 N.Y. LAW REVISION COMOM'N REPORT 1108 (1954). One bank representative predicted that the outright prohibition of waiver clauses in consumer sales contracts would lead to increased litigation, reduction in the amount of credit available, and substantial increases in the financing charges.

$\$ 1$ Consumer goods are defined in UCC § 9-109(1) as goods which "are used or bought for use primarily for personal, family or household purposes."

42 UCC \& 9-206(1).

43 Colorado (Colo. Rev. Stat. ANn. \$ 155-9-206 (1963)) and California (Car. Comom. CODE 9206 (1963)) have both deleted the words "or decision." California deleted the phrase because it was thought that provisions of the Unruh Act sufficiently covered the problem. Littlefield, Good Faith Purchase of Consumer Paper: The Failure of the Subjective Test, 39 S. GaL. L. Rev. 48, 75 (1966). The Permanent Editorial Board for the Uniform Commercial Code has rejected these deletions. REPORT No. 2 of THE PERMANENT EdTroriaI BOARD FOR THE UCC 187 (1964).

44 Recent Decisions, Unconscionability and the Consumer's Waiver of Defenses, 56 Gro. L.J. 997, 999-1000 (1968); Comment, Commercial Transactions: Section 9-206 and Its Applicability to the Tripartite Credit Card, 21 OKLA. L. REv. 59, 61 (1968). 
ceptions. Such an interpretation was not the purpose of the section and the official comment makes this clear. The comment states that the section "takes no position on the controversial question whether a buyer of consumer goods may effectively waive defenses by contractual clause or by execution of a negotiable note." 45 This statement would be a rather awkward means of stating the so-called "prior law" theory for use of the section. ${ }^{46}$ Therefore if a court proceeds to establish a new rule in the state, as did the Unico court, ${ }^{47}$ it is not acting beyond the scope of the Code.

The courts are thus authorized, using section 9-206(1), to invalidate consumer waiver agreements. Such action would have little effect on the parties' positions if a note was given in the transaction and the financer qualified as a holder in due course and was allowed to recover on that basis. Such a result does not appear to be the Code's intention. Section 9-206 states that a buyer who has signed both a negotiable instrument and a security agreement as part of the same transaction has made a waiver agreement of the type with which the section deals. ${ }^{48}$ It is submitted that when a court declares a consumer waiver of defenses invalid, it has simultaneously denied recovery on the note, which is itself a waiver. Several provisions of the Code point towards this conclusion. The text and comments to sections $9-105(1)(b)$ and $9-105(1)(g)^{49}$ state that a negotiable note and a conditional sales contract executed together are "chattel paper" and that the rules of article 9, rather than those of article 3, are applicable to it. This is a restatement of the provision in section 3-10350 that the provisions of article 3 are subject to the provisions of article 9 . By making both a security agreement

45 UCC \$ 9-206, comment 2.

46 Professor Soia Mentschikoff, Associate Chief Reporter for the Code and consultant to the Permanent Editorial Board states that by means of $\S 9-206$ "the court is invited to protect the ultimate consumer against the cutting off of his defenses ... if that course seems wise to the court." Mentschikoff, supra note 38, at 171 (emphasis added). See also 2 G. GILMORE, supra note 38, at 1093.

4750 N.J. 101, 125, 232 A.2d 405, 418 (1967).

48 See the last sentence of UCC \$ 9-206(1) quoted note 27 supra.

49 UCC \& 9-105(1)(b) provides: "Chattel paper" means a writing or writings which evidence both a monetary obligation and a security interest in or a lease of specific goods. When a transaction is evidenced both by such a security agreement or a lease and by an instrument or a series of instruments, the group of writings taken together constitutes chattel paper;" UCC \$ 9-105(1)(g) provides: “'Instrument' means a negotiable instrument (defined in Section 3-104),..."

Comment 4 to $\$ 9-105$ provides in part: "Chattel mortgages and conditional sales contracts are frequently executed in connection with a negotiable note or a series of notes. ... [T] he rules applicable to chattel paper, rather than those relating to instruments, are applicable to the group of writings (contract plus note) taken together."

50 UCC \$ 3-103 provides in part: "(2) The provisions of this Article are subject to the 
and a negotiable note, the buyer has created chattel paper whose elements may not be severed. If article 9 denies recovery on the sales contract, one element of the chattel paper, it has automatically denied recovery on the note, even though the holder is a holder in due course. By giving effect to the consumer exception in section 9-206(1), the court has fully protected the consumer and need not consider holder in due course arguments. Were this not so, section 9-206(1) would provide no protection to the consumer in any state which allowed the use of negotiable notes in consumer transactions.

If the court hearing a waiver of defenses case decided that the state's policy should be to validate the consumer waiver of defenses, the financer would still have to meet the other requirements of section 9-206(1). It must prove that it took the contract in good faith, for value, and without notice of a claim or defense except as to defenses which could be asserted against a holder in due course. These are the same requirements which a holder must meet to qualify as a holder in due course and will be discussed in the section below dealing with holders in due course. However, denials of recovery based on such factors require full litigation and do not offer the same protection as a state's outright prohibition of the use of consumer waiver agreements.

In any consumer transaction in which an assignee is involved and the seller fails to provide the promised consideration, either the assignee or the buyer will have to sustain a loss. ${ }^{51}$ Section 9-206 gives the courts the power to allocate this burden to the financer, even if the financer acted in good faith. It is submitted that the Code allows courts to provide the same outright prohibition of use of waiver of defenses clauses in consumer contracts as was specifically included in the 1952 edition of the Code. ${ }^{52}$ The Code thus invites the courts to establish a policy of putting the burden of non-performance on the financer, and they should feel free to do so where the burden is not already placed on the financer by statute.

provisions of the Article on ... Secured Transactions (Article 9)."

51 This assumes that there is no worthwhile cause of action against the seller. Even if the seller is worth suing, the financer is much more likely to have the resources to sue. If the financer is the party who will sustain a loss if the seller fails to perform, he will be prone to police the seller and stop dealing with those who appear to be bad risks. There is no corresponding possibility for a buyer to police sellers.

ס2 When giving effect to § 9-206 and allocating the burden of nonperformance to the financer, courts should also allow breach of warranty to be pleaded as one of the defenses of the consumer. See State Nat'l Bank v. Cantrell, 47 N.M. 389, 143 P.2d 592 (1943) which allowed the defendant-buyer to plead breach of warranty as a counterclaim in an action against him by the financer for nonpayment of installments due on a conditional sales contract. 


\section{B. The Application of Unconscionability Provisions to the Use of Section 9-206}

The Unico court did not rely on section 9-206(1) alone to invalidate the waiver of defenses clause, but rather discussed the section in terms of the Code's unconscionability provisions. ${ }^{53}$ This introduction of unconscionability considerations raises two questions: first, whether section 9-206 should be specially linked with section 2-302; and, second, whether consumer waivers of defenses can be properly termed unconscionable without extensive investigations in each case.

There is nothing on the face of sections 2-302 and 9-206 which would indicate that there is any special relationship between them. Neither section contains cross-references to the other. As has been seen, comment 2 to section $9-206^{64}$ states that no position is taken regarding the validity of consumer waivers. This would make little sense and serve no purpose if the use of waiver clauses in consumer agreements was regarded as being automatically unconscionable. If the clauses were unconscionable, the Code would not leave the decision whether to enforce them to the discretion of the states. An unconscionable clause is never enforceable, and no section other than 2-302 is required to deny enforcement, provided that the court makes the necessary findings. ${ }^{55}$

Waiver clauses do not meet the requirements which the Code sets out for a finding of unconscionability. The unconscionability section has been subjected to various interpretations regarding its proper use..$^{56}$ Some writers see it as a convenient escape hatch for a court which finds itself without a more explicit statutory provision by which it can achieve the desired result. ${ }^{.77}$ Nevertheless, certain definite findings are required before the section may properly be invoked. ${ }^{58}$ Cases in-

53 See text at note 28 supra.

54 See text at note 45 supra.

55 Comment 1 to $\S 2-302$ states: "The principle is one of the prevention of oppression and unfair surprise (cf. Campbell Soup Co. v. Wentz, 172 F.2d 80 (3d Cir. 1948) and not of disturbance of allocation of risks because of superior bargaining power."

56 See generally the discussions in Leff, Unconscionability and the Code-The Emperor's New Clause, 115 U. PA. L. REv. 485 (1967) and Ellinghaus, In Defense of Unconscionability, 78 YALE L.J. 757 (1969).

57 Professor Leff has referred to § 2-302 as a "high level abstraction." Leff, Unconscionability and the Code-The Emperor's New Clause, 115 U. PA. L. REv. 485, 557 (1967).

58 Comment 1 to UCC $\$ 2-302$ quoted at note 55 supra. See, e.g., Williams v. WalkerThomas Furniture Co., 350 F.2d 445 (D.C. Cir. 1965). In that case buyer made various purchases on several conditional sales contracts. Each contract provided that if buyer defaulted in any payment, all goods purchased which had not been fully paid for could be repossessed. The financer credited the payments in such manner that there was always a small balance due on each item. When buyer defaulted in payments on one of the last items purchased, the financer attempted to repossess all of the goods. This case clearly contains the requisite elements of surprise and oppression, and reversing a lower court, 
volving "referral schemes," under which the contract buyer is led to believe that he will pay for goods by making referrals of potential customers to the seller, frequently are decided on the basis of unconscionability. Such decisions, exemplified by the recent case of Frostifresh $v$. Reynoso, 59 contain the requisite elements of surprise and oppression. But the only element of surprise which the court could find in the standard waiver of defenses clause would be that the clauses are usually printed in small type and could easily be overlooked by the buyer. ${ }^{60}$ Otherwise, the inclusion of such a clause is an allocation of risks based on differences in bargaining power-something which the comment to section 2-302 would exclude from the protection of that section. The fact that the waiver clause was included by the seller at the instance of the "closely associated" financer will quite properly prompt the court to act. While such a relation, after proper analysis, is sufficient basis for a finding that the assignee did not act in good faith, ${ }^{01}$ it is not a proper basis for determining whether a clause is unconscionable. The unconscionability of a clause is not determined by the external factors which determine whether the assignee took in good faith. Thus the waiver of defenses clause in a conditional sales contract or other security agreement signed by a consumer may be "improvident," but not unconscionable. ${ }^{62}$

If a court should find that a contract has been unconscionable for the reasons given in section 2-302, it may, of course, refuse to enforce it. However, in most cases, adding references to the unconscionability provisions of the Code can only confuse the issue. In Unico it is uncertain whether the court established unconscionability as a prerequisite for use of section 9-206 in the consumer context. Such a pre-

the court of appeals remanded for a determination of the unconscionability question, strongly indicating it thought the contract was unconscionable. Id. at 449-50. The Unico court cited this decision as precedent for its statements regarding unconscionability. However, the elements of surprise and oppression in a case such as Williams $\nu$. Walker-Thomas Furniture Co. are clearly lacking in Unico.

5954 Misc. 2d 119, 281 N.Y.S.2d 964 (Sup. Ct. 1967). The facts, stated at 52 Misc. 2d 26, 274 N.Y.S.2d 757 (1966) are as follows: A freezer which cost seller $\$ 348$ was sold to the buyer for $\$ 1,145.85$ with representations to buyer that the freezer would cost him nothing because of his participation in a referral plan. At trial it was proven that it was mathematically impossible for the referral plan to work as promised. The court found that on these facts the contract was unconscionable. Fraud was not raised as a defense at trial and was not considered.

60 A. Corbin, Contracts $\$ 128$ (1963 ed.). It could of course be argued that such small print clauses are an unfair surprise to the consumer and have oppressive results if sustained. However, the fact that enforcing a clause will have adverse effects on the consumer does not necessarily mean that it is unconscionable.

61 See text at notes 82-84 infra.

62 Star Credit Corp. v. Molina, 59 Misc. 2d 290, 298 N.Y.S.2d 570, 575 (New York City Ct. 1969). 
requisite would be unfortunate because it would tend greatly to restrict courts' use of section 9-206. The additional factor of unconscionability could significantly strengthen the position of the financers. Since waiver of defenses clauses are not per se unconscionable, the New Jersey court's reasoning would require proof in each instance of the required elements. This would prevent summary judgment for buyerdefendants in the waiver cases and require full litigation. The use of waiver clauses, written in type large enough that buyers could not claim to have overlooked them and accompanied by some sort of explanation, would be encouraged rather than deterred. ${ }^{63}$ These issues were not dealt with in Unico and consequently the status of waivers of defenses in New Jersey remains in doubt. However, in subsequent cases in other jurisdictions, courts should avoid basing decisions on unconscionability arguments. Section 9-206, by itself, will give the consumer full protection.

\section{Holder in Due Course Status of CONSUMER Financers}

If a court hearing a consumer paper case does not fully use the provisions of section 9-206, full consumer protection will depend on the court's use of the Code's holder in due course provisions. This would be the situation if the court was reluctant to establish a new rule, or if the transaction involved only a note, in which case the chattel paper issue would not be raised. In other circumstances, courts simply may prefer to proceed along an analysis of holder in due course qualifications rather than making a statement of the contract rights. In any of these situations, prior law and the Code provisions, if properly used, will protect the consumer from having to pay for goods which were never received. ${ }^{64}$

63 If sellers thought that there was a possibility that the waiver of defenses clauses might be upheld if found not to fit the $\$$ 2-302 definition of unconscionability, they could be expected to use them in every transaction. In any event such use would have some in terrorem value when a financer tried to force payment before actually beginning suit. Sellers would not object if required to explain the clauses to buyers if as a result the clauses were recognized as valid. Those who finance their purchases of consumer goods do so because of necessity. They would have either to sign the agreement as explained by the seller, or do without the goods, so the giving of an explanation, however complete, would not result in eliminating the waiver problem.

64 The denial of holder in due course status is discussed here only in a consumer context. That is the area in which the problems discussed here would most frequently arise, since commercial borrowers tend to borrow directly from a financing institution and then purchase from the seller for cash. However, whenever the situation is that of the purchaser signing a note to the seller who assigns it to a financer, the commercial borrower can take advantage of any remedies available to the consumer under like circumstances: either the party-to-the-transaction rule or good faith and notice grounds. 


\section{A. The Party-to-the-Transaction Rule}

The party-to-the-transaction rule refers to a denial of holder in due course status to the financer because of his extremely intimate association with the seller. The application of this rule does not require an analysis of either the good faith of the taker or whether there was notice of any defects. This is because the financing agency in such a transaction is not considered to be a transferee of the note at all. Rather it is regarded as being involved in the original transaction, just as if the note had originally been payable to it instead of to the seller. This rule grew up alongside the holder in due course requirements of the NIL and was not considered to be in conflict with them. ${ }^{65}$ Courts frequently used the party-to-the-transaction rule without even bothering to refer to the NIL. It is submitted that the rule remains in effect with the adoption of the Code, ${ }^{66}$ and that in proper situations, it may be employed just as it was when the NIL was the governing law regarding holders of negotiable notes.

A recent case in which holder in due course status was denied on the basis of the party-to-the-transaction rule is Jones $v$. Approved Bancredit Corp. ${ }^{67}$ That case involved a contract for construction of a home. The buyer had executed a note payable to Albee Dell Homes, Inc., (Dell), the construction company, which immediately assigned it to Approved Bancredit Corp. (Bancredit). Both Dell and Bancredit were wholly owned subsidiaries of Albee Homes, Inc., and they had the same officers and directors. Bancredit had been formed by Albee Homes, Inc., solely to take assignments of contracts and notes made payable to its other subsidiaries and ninety-nine per cent of its business came from them. ${ }^{88}$ Dell failed to perform the contract; Mrs. Jones refused to make any payments; and Bancredit brought suit for payment of the note claiming

65 Buffalo Indus. Bank v. DeMarzio, 162 Misc. 742, 296 N.Y.S. 783 (Buffalo City Ct. 1987), rev'd on other grounds, 6 N.Y.S.2d 568 (1937), was an early use of the party-to-thetransaction rule. The rule was to some extent the basis for the Unico holding. The court states both that it is reaching a result which fits the Code's requirements and that the position of Unico was one in which it should be considered a "participant in the original transaction." 50 N.J. 101, 123, 232 A.2d 405, 417 (1967). See also Littlefield, Good Faith Purchase of Consumer Paper: The Failure of the Subjective Test, 39 S. CAL. L. REv. 48, 68 (1966).

66 UCC \& 1-103 provides: "Unless displaced by the particular provisions of this Act, the principles of law and equity, including the law merchant and the law relative to capacity to contract, principal and agent, ... or other validating or invalidating cause shall supplement its provisions."

o7 256 A.2d 739 (Del. Sup. Ct. 1969). The only mention which the Delaware Supreme Court made to either the UCC or the NIL was a footnote reference to the good faith requirement and the defenses available against one not a holder in due course. $I d$. at $741 \mathrm{n} .3$.

68 Id. at 741 . 
to be a holder in due course. After noting the similarity of this case to Unico, the court denied holder in due course status:

By reason of its sister corporation relationship to Dell and the established course of dealing between them, Bancredit was more nearly an original party to the transaction than a subsequent purchaser of the paper; and for the reasons of fairness and balance stated in the foregoing authorities, Bancredit should be denied the protected status of holder in due course ....69

Use of the party-to-the-transaction rule will be available only where the relation between the financer and the seller was so close that the financer had control over the seller. ${ }^{70}$ This will be in situations in which there was common ownership of the entities, common officers, or both. On facts such as those in Jones $v$. Approved Bancredit Corp. both of these requirements are met, and it is clear that the financer functioned entirely at the whim of the seller. When there is common ownership of the seller and financer, there are no additional profits to be made by assignment of the note from one sister corporation to another, so long as the parties perform their contract obligations. Rather, the presence of the financer is designed to insure that the buyer will bear any loss resulting from the seller's default. To refer to the financer as an original party to the transaction is not a legal fiction, but a statement of its actual relationship to the parties. ${ }^{71}$

69 Id. at 743. The "foregoing authorities" referred to included Commercial Credit Co. v. Childs, 199 Ark. 1073, 137 S.W.2d 260 (1940); Mutual Finance Co. v. Martin, 63 So. 2d 649 (Fla. Sup. Ct. 1953); Unico v. Owen, 50 N.J. 101, 232 A.2d 405 (1967); Buffalo Indus. Bank v. DeMarzio, 162 Misc. 742, 296 N.Y.S. 783 (Buffalo Gity Ct. 1937), rev'd on other grounds, 6 N.Y.S.2d 568 (1937).

At various points the rule used is referred to as "the rule of balance," referring to a desire to balance a general desire for free flow of paper with the interests of those signing such paper. Concluding the opinion the court said:

The rule we here adopt must be applied carefully because of the delicate balance of the interests of the installment-buying community and the commercial community. But the need for special care in application should not foreclose the adoption of the rule and its application in a proper case. In this day of demonstrated need for emphasis upon consumer protection and truth in lending, special consideration must be given to preventing the misuse of negotiable instruments to deprive installment purchasers of legitimate defenses. $I d$.

70 Whether the financer had control over the seller or whether they had common officers would not need to be considered if it was proven that the financer actually participated in negotiating the transaction. That was the situation in Commercial Credit Co. v. Orange County Machine Works, 34 Cal. 2d 766, 214 P.2d 815 (1950).

71 It is quite possible that a seller will establish a separate legal entity to handle the financing of his sales for reasons other than the one suggested in the text. For example, legal separation of the two aspects of his business might be desirable if the risks of loss in the sales transactions were much lower than those in the financing of the transactions. However, such a reason for the separate legal entities would not affect the analysis of the problem under consideration here. Regardless of the purpose for the separation, the 
The facts in Unico, while nearly identical to those in Jones $v$. Approved Bancredit Corp., do not show the same element of control as in the latter case. The financer in Unico had great influence over the seller but apparently did not have actual control. In such a case a court should not deny holder in due course status by holding that the financer was a party to the transaction. Rather it will have to treat the financer as a transferee of the note, and then proceed to determine whether it met the requirements set out in UCC section 3-302.

\section{B. Good Faith and Notice Requirements for Holder in Due Course Status Under the UCG}

When the NIL was the governing law, courts generally denied holder in due course status to a financer in cases similar to Unico. ${ }^{72}$ NIL sections 52 and 56 defined the holder in due course and his rights, ${ }^{73}$ and subjected one claiming such status to both good faith and notice requirements. In applying the NIL sections, courts sometimes used an objective standard ${ }^{74}$ to determine whether the holder took the note in good faith. Code section 3-302 includes both good faith and lack of

relationship is viewed in the same way in determining whether the financer can qualify as a holder in due course.

72 See Gilmore, The Commercial Doctrine of Good Faith Purchase, 63 YALE L.J. 1057, 1099 (1954); Jones, Finance Companies as Holders in Due Course of Consumer Paper, 1958 WASh. U.L.Q. 177, 182-4; cases cited notes 7 \& 8 supra.

73 NIL § 52 provides:

What Constitutes a Holder in Due Course. A holder in due course is a holder who has taken the instrument under the following conditions:

1. That it is complete and regular upon its face;

2. That he became the holder of it before it was overdue, and without notice that it had been previously dishonored, if such was the fact;

3. That he took it in good faith and for value;

4. That at the time it was negotiated to him he had no notice of any infirmity in the instrument or defect in the title of the person negotiating it.

NIL § 56 provides:

What Constitutes a Notice of Defect. To constitute notice of an infirmity in the instrument or defect in the title of the person negotiating the same, the person to whom it is negotiated must have had actual knowledge of the infirmity or defect or knowledge of such facts that his action in taking the instrument amounted to bad faith.

74 When a statute requires good faith conduct in order for one to come within its protection, criteria used may be said to be either objective or subjective. The objective standard is usually traced to an English case, Gill v. Cubitt, 3 B. \& C. 466 (1824). That case required that to meet the good faith requirement, the holder prove that when he took the instrument, he made inquiries which would have been made by a reasonably prudent man. He was charged with notice of what such a reasonably prudent man would have learned on inquiry and his actual state of mind was not considered. Under a subjective standard, which it is felt will facilitate easy flow of commercial paper, the holder's state of mind rather than compliance with a general prudent man standard determines if he took in good faith. See Farnsworth, Good Faith Performance and Commercial Reasonableness Under the Uniform Commercial Code, 30 U. CHI. L. REv. 666 (1963); see generally Littlefield, Good Faith Purchase of Consumer Paper: The Failure of the Subjective Test, 39 S. CAL. L. Rev. 48 (1966). 
notice of defects requirements for the holder to qualify as one in due course. Good faith is defined as "honesty in fact in the conduct or transaction concerned."'75 Like the wording of section 9-206, the good faith requirement of section 3-302 represents a retreat from the wording of the 1952 edition of the Code, which required "good faith including observances of reasonable commercial standards of any business in which the holder may be engaged."78 There was widespread dissatisfaction with the 1952 definition of holder in due course, mostly on the part of financing agencies. ${ }^{77}$ They believed that the language had made a radical change in negotiable instruments law and had created a purely objective test under which the holder's compliance with the standard of a reasonably prudent man rather than his state of mind would be determinative. As a result of this opposition, the definition was changed to its present form. The reason given was "to make clear that the doctrine of an objective standard of good faith, exemplified by the case of Gill v. Cubitt . . . is not submitted to be incorporated in Article 3."78 This change apparently satisfied the critics that the holder in due course requirements remained the same as under pre-Code law.

Since the Code requires that good faith be determined not by the purely objective standards of Gill $v$. Cubitt, but by the standards employed in pre-Code adjudication, the result in a case such as Unico must be reconciled with such a test. As noted above, the opponents of the 1952 edition's holder in due course requirements believed that it would make a substantial change in the existing law, but that the present version retained the pre-Code law. What then was the state of the law prior to the Code's enactment? The law of New York is instructive, and it is submitted, representative, of the prior law on the good faith requirement for holder in due course status. An analysis of New York cases over a period of approximately seventy-five years prior to the adoption of the Code shows that in each case the patterns and practices of the business in which the holder was engaged were used as a standard to determine whether he took in good faith. ${ }^{79}$ In all of the cases, evi-

75 UCC \& 1-201(19).

76 Uniform Commercial Code, 1952 Official Draft \& 3-302(1)(b) (emphasis added). The official comment stated that this language made explicit what had long been the case law and that a holder's qualifications as a good faith holder would depend on the nature of his business.

77 There was considerable opposition from banking interests when UCC \& 3-302 was considered by the New York Law Revision Commission. 2 N.Y. LAW REvision Comm'N REPORT 1318, 1336-7 (1954).

78 Uniform Commercial Code, 1952 Offictal. Draft 18-19 (Supp. I, 1955).

79 That the prior law of New York based good faith on the patterns and practices of the trade was conclusively demonstrated in a memorandum submitted to the New York Law Revision Commission by Professor Soia Mentschikoff. 1 N.Y. LAw Revision Comm'N 
dence was submitted to show the regular practices of the holder's trade, the relationship between the holder and seller who assigned the note, and the circumstances under which the note was taken. This information was submitted to the jury which determined whether the holder had so deviated from the patterns and practices of the trade that it had not acted in good faith. The taker was not judged by a universal test for reasonably prudent men taking commercial paper. ${ }^{80}$ Each case was decided on the basis of the holder's conduct in the instant transaction. That the objective standard of Gill $v$. Cubitt was not employed in these cases may be seen by the fact that conduct which might be considered good faith in one case, would be considered bad faith in a different context. ${ }^{81}$

The Unico court was using a proper subjective standard when it referred to an analysis of the "totality of the arrangements" 82 between the seller and the financer. Evidence setting forth the totality of arrangements will be used as basic criteria in determining whether there was good faith. The analysis will include evidence of the extent to which the financer had influence over the seller. The fact that there was some influence or an agreement or that the seller was required to use financer's preprinted forms will not dictate automatic denial of holder in due course status. ${ }^{83}$ The fact that this analysis is conducted

REPORT 213 (1954). Miss Mentschikoff analyzed approximately twenty-five leading New York cases involving good faith taking of negotiable instruments, and found that the determining criterion was whether the holder's conduct met the accepted patterns and practices of his trade. Miss Mentschikoff summarized the analysis by stating: ". . . in the New York courts ... the question of 'good faith' has always been resolved in the light of ... what in effect amounts to the criterion of 'reasonable commercial standards.' The judges may not have talked in terms of such a standard. What they have done is more cogent. What they have done is to apply the standards-and ... . with amazing consistency." Id. It therefore appears that the Code's present requirement of good faith for a holder, by purporting to make no change in prior law, has authorized a commercial reasonableness test subject to the specific proviso that this not be transformed into a Gill v. Cubitt test. See note 80 infra and text at note 78 supra.

80 This difference was pointed out during the New York Law Revision Commission hearings by comparing the good faith requirement in the 1952 draft of $\S 3-302$ with the good faith requirement for a merchant in article 2 . The merchant was held simply to "reasonable commercial standards" without any qualification of the business in which he was engaged. This was a Gill $v$. Cubitt or reasonably prudent man standard. Such a general standard was objective and could be the basis for directed verdicts. However, the additional qualification in \$ 3-302 prevented use of a general prudent man standard. The holder's actions would have to be examined in light of the practices of his trade to determine if he had acted honestly in fact-a subjective standard with the decision reserved for the trier of fact. 1 N.Y. LAW REvision COMM'N REPORT 520-8 (1954).

81 See Memorandum of Professor Soia Mentschikoff, 1 N.Y. LAW REvision Comm'N REPORT 213, 215-20 (1954).

8250 N.J. 101, 124, 232 A.2d 405, 417 (1967). See text at note 25 supra.

83 Such a denial would meet the exact definition of an objective standard. 
with reference to basic criteria does not mean that it is an objective test any more than the fact that there are basic criteria in the Code makes those requirements an objective test.

The court in determining whether a holder took in good faith is not examining the state of its mind on a particular day. Rather, it is ascertaining whether there was a continuing state of mind, throughout the course of dealings between the financer and seller, which did not meet the Code's requirements. The agreement between the seller and financer and the facts of the financer's creation in Unico are representative of such a course of dealing. The relationship between Unico and Universal shows a marked variation from that of a finance company which had merely extended a line of credit to a particular seller ${ }^{84}$ After hearing evidence that the financer departed from the patterns and practices of the trade, the jury should be instructed that it may draw an inference of lack of good faith from the variation, although the fact of the variation would not authorize a directed verdict against the holder.

In many respects, the analysis of whether the financer acted in good faith resembles an analysis of whether he met the notice requirements of section 3-302.85 It has been held, for example, that knowledge of the seller's methods of doing business is a sufficient basis for denial of holder in due course status after a default. ${ }^{86}$ When the financer has rights to inspect seller's records and remain cognizant of all aspects of its business, it should be aware of any likelihood that the business would fail and that the seller would be unable to perform. The extent to which such facts are apparent will be again a question for the jury. Since the note is usually assigned immediately after its execution, there is seldom a default at that time. ${ }^{87}$ Therefore the test is not whether the financer knew of a defect at the time of the taking, but rather whether it should have known of the great likelihood of a default. As in determining the good faith issue, the entire course of dealings with the seller will have to be analyzed. If the seller had previously assigned paper to the financer and then failed to perform the underlying obliga-

84 Nearly all sellers of consumer goods will make an agreement that a particular financer agrees to accept paper from their sales. This is necessary in order to be sure of obtaining financing for their credit customers. Thus an agreement between the parties is not a variation from practices and patterns of the trade. However, the greater the influence which the financer gets over the seller, the greater is the departure from normali practices.

85 UCC \& 3-302(1)(c).

86 Davis v. Commercial Credit Co., 87 Ohio App. 311, 94 N.E.2d 710 (1950).

87 The unusual situation is represented by Industrial Credit Co. v. Mike Bradford \& Co., 177 So. $2 d 878$ (Fla. 1965) in which the seller had already defaulted at the time that it assigned the paper to the financer and the financer knew this fact. 
tion, ${ }^{88}$ the financer had notice of the business methods of the seller and should be treated as having notice of a defect in the paper which it received. ${ }^{89}$ The financer should not be allowed to claim lack of notice when a full exercise of its contract rights would have revealed the likelihood that the seller would not be able to perform. ${ }^{90}$ Otherwise the financer might choose to protect itself by refusing to exercise contract rights and thereby intentionally remaining ignorant of the facts. Such conduct would probably also be grounds for good faith denial of holder in due course status.91

When the installment sale purchaser pleads failure of consideration, the seller may have failed to perform, not because of insolvency, but because his purpose in entering the transaction was to defraud the purchaser. Frequently dishonest sellers are in business not to make a profit from the sale of goods, but to obtain commercial paper by fraudulent representation. ${ }^{92}$ Such a financer may be denied holder in due course status on several of the grounds discussed here. If the financer was created by the dishonest seller, there can be no question of its being a party to the fraud and holder in due course status should be denied. Any other financer which had knowledge of all aspects of the seller's business

88 Effective notice of the business methods of unscrupulous sellers might be given by the legal aid bureaus in the various cities. When a legal aid bureau learned of a seller who had failed to meet his contract obligations, it could immediately notify the financers of that seller's business methods. The financers would thus be put on notice should they ever take any of the seller's paper, even if they had had no previous dealings with him.

80 Just as previous failures of consideration by the same seller would have given the financer notice of a defect, so would previous breaches of warranty. If the seller had previously delivered deficient goods, the financer had reason to know of possible future breaches of warranties. The past transactions put him on notice of the seller's business methods which included the delivery of deficient goods.

00 The fact that a dealer was engaged in a business often pervaded by fraud should cause the financer to make inquiry into the seller's business affairs. It has been held under UCC \$ 3-802 that failure to make inquiry because an unfavorable result might be discovered is sufficient grounds for denial of holder in due course status. Norman v. WorldWide Distributors, Inc, 202 Pa. Super. 53, 195 A.2d 115 (1963).

91 See Beatty v. Franklin Investment Co., 319 F.2d 712 (D.C. Cir. 1963); Investment Credit Co. v. Mike Bradford \& Co., 177 So. 2d 878 (Fla. Dist. Ct. App. 1965); HIMC Inv. Corp. v. Siciliano, 103 N.J. Super. 27, 246 A.2d 502 (1968); Davis v. Commercial Credit Co., 87 Ohio App. 311, 94 N.E.2d 710 (1950).

92 A recent case in which this was the situation is Star Credit Corp. v. Molina, 59 Misc. 2d 290, 298 N.Y.S.2d 570 (New York City Ct. 1969). Fraud by the seller has been especially common in the home improvement industry. The sellers of home improvement contracts frequently disappear shortly after making a sales agreement and carefully negotiating the resulting documents to a financer. See, e.g., American Home Improvement, Inc. v. Maciver, 105 N.H. 435, 201 A.2d 886 (1964); Davis v. Commercial Credit Co., 87 Ohio App. 311, 94 N.E.2d 710 (1950); Fidelity Trust Co. v. Gardiner, $191 \mathrm{~Pa}$. Super. 17, 155 A.2d 405 (1959); First Pennsylvania Banking \& Trust Co. v. DeLise, $186 \mathrm{~Pa}$. Super. 398, 142 A.2d 401 (1958); Burchett v. Allied Concord Financial Corp., 74 N.M. 575, 396 P.2d 186 (1964). 
would be aware that the paper was being obtained by fraudulent means and of the planned default by the seller. The presence of the financer is the link which makes the scheme workable, and the position of the financer is little more than that of a conspirator to defraud the public. Such a financer appears unable to satisfy either the good faith or lack of notice requirements.

\section{ConClusion}

The UCG contains protection for the consumer sued by a financer who claims to be a holder in due course of the consumer's note and to be entitled to the benefit of any waiver of defenses in the consumer sales agreement. Proper application of such protective provisions is illustrated by Unico $v$. Owen which denied the financer the protected status which it sought both as a holder and as an assignee. The key elements of the denial of holder in due course status in that case are the reference to the "totality of arrangements" and the finding that "Unico not only had a thorough knowledge of the nature and method of operations of Universal's business, but also exercised extensive control over it." 93 Such findings authorize juries to deny holder in due course status on good faith grounds and sometimes on notice grounds. In some cases, the financer will be so closely related to the seller that there will be no jury question and the court can direct verdict for the buyer or give summary judgment.

Complete consumer protection requires that the courts use section 9-206 to invalidate consumer waivers of defenses clauses. This section prevents recovery by the financer in any case in which it would not qualify as a holder in due course. More importantly, even when the financer would be entitled to holder in due course status, section 9-206 can be used to deny recovery by invalidating the waiver. Courts should establish a policy of invalidating such waivers whenever, as a result of the seller's failure to perform, loss must fall on either the financer or on the consumer.

Further legislation such as the Uniform Consumer Credit Code would also protect consumers in the situations discussed here. However, the Uniform Consumer Credit Code has only recently been promulgated. ${ }^{94}$ Regardless of the merits of such legislation, ${ }^{95}$ it is attractive

9350 N.J. 101, 115, 232 A.2d 405, 413 (1967).

94 Oklahoma and Utah are the only states to have adopted the Uniform Consumer Credit Code thus far. 14A OrLa. Stat. ANN. §§ 1-101 to 9-103 (Supp. 1969); 7B UTAF CodE ANN. \$\$ 70B-1-101 to 9-103 (Supp. 1969).

95 The use of the Uniform Consumer Credit Code as the instant panacea to all consumer problems has been questioned. Hogan, Integrating the UCCC and the UCCLimitations on Creditors Agreements and Practices, 33 LAW \& ConTEMP. Prob. 686, 688-9 (1968). 
as a solution only to the extent that its adoption is certain and that existing legislation is inadequate to deal with the problem. It is submitted that the UCC adequately deals with the problems presented by waiver of defenses clauses and claims to holder in due course status in the consumer context. The Code is now law in all but one jurisdiction in the United States, ${ }^{98}$ and courts should use it to protect the consumer from the abuses of installment credit sales.

90 All of the states except Louisiana have adopted the Code. 